Василь Вікторович Кузавков (доктор технічних наук, доцент)

Марія Михайлівна Романенко

Юлія Володимирівна Болотюк

Військовий інститут телекомунікацій та інформатизації імені Героӥв Крут, Київ, Україна

\title{
УМОВИ ЗАСТОСУВАННЯ МЕТОДУ ВЛАСНОГО ВИПРОМІНЮВАННЯ ПРИ ВИРІШЕННІ ЗАДАЧ ТЕХНІЧНОЇ ДІАГНОСТИКИ НАПІВПРОВІДНИКОВИХ СТРУКТУР
}

\begin{abstract}
В статті розглянуто особливості застосування методу власного випромінювання для складних напівпровідникових структур (мікропрочесорів, мікроконтролерів, програмовано-логіних інтегральних схемах та ін.)

Метод власного випромінювання пов'язаний з реєстрацією параметрів електромагнітного поля 8 інфрачервоному діапазоні хвиль. Параметри иьього випромінювання безпосередньо залежать від температури об'єкту контролю - температури напівпровідникової структури. Використання температури в якості діагностичного параметру вимагає аналітичного опису процесів 6 напівпровідникових структурах, а саме фізико-хімічних процесів пов'язаних з термодинамічними властивостями кристалічної структури та поверхні, яка ізолює кристал від зовнішнього середовища.

3 метою активації функціональних вузлів, які входять до складу великих інтегральних схем в запропонованому методі використовується спеціально підготовлена тестова послідовність. Довжина зазначеної послідовності повинна забезпечити вихід температурного процесу на сталий режим. Однак, при иьому можливе спотворення діагностичної інформації внаслідок взаємного впливу температури від сусідніх функціональних вузлів. В роботі визначено час реєстрації (довжину активуючого впливу) діагностичного параметру окремих функціональних вузлів. Проаналізовано умови розповсюдження тепла в ізолюючому шарі напівпровідникової структури, яка містить в собі декілька окремих функиіональних вузлів з відомим геометричним місцем розташування на підложиі.

Дослідження спрямовані на вирішення задач технічного діагностування, а саме: визначення фактичного технічного стану ичифрового радіоелектронного обладнання та прогнозування технічного стану.
\end{abstract}

Ключові слова: метод власного випромінювання, час реєстрації діагностичного параметру, радіоелектронне обладнання, велика інтегральна схема.

\section{Вступ}

Розвиток радіоелектронного обладнання (РЕО) відкриває нові можливості розвитку суспільства. Однак, будь-яка техніка має свій життєвий цикл. Для запобігання виникненню непередбаченого виходу з ладу технічних засобів (Т3) необхідно проводити комплекс заходів по перевірці їх технічного стану (ТC) - заходів технічного діагностування. Особливо, це стосується устаткування, вихід 3 ладу якого, створює загрозу безпеці країни або життю людини.

Постановка завдання. До складу сучасних технічних засобів, які використовується в ЗС України, входить велика кількість пристроїв виготовлених на основі єдиної великої інтегральної схеми (ВIC) (процесор обчислювальної машини; надвеликі інтегральні схеми комутаторів, маршрутизаторів; периферійних пристроїв, програмовані логічні інтегральні схеми та інші).

3 метою реєстрації та обробки діагностичної інформації, необхідно проаналізувати технологію виготовлення сучасних високонадійних ВIC їх внутрішню структуру та механізм передачі діагностичних ознак (в методі власного випромінювання - тепло) від “нагрітого” кристалу на поверхню до пристрою реєстрації внаслідок виконання основних функцій.

Аналіз останніх досліджень і публікацій. Аналіз джерел [1-14] показав існування високоефективного безконтактного методу вирішення задач технічні діагностики - методу власного випромінювання. Застосування та розвиток даного методу $є$ актуальною науковою задачею особливо для прогнозування ТC ВIC (процесорів, програмовано логічних інтегральних схем та ін.). Діагностичний параметр (ДП) в методі власного випромінювання формується у відповідності до способу перенесення теплової енергіï [1]. В роботі [2] показано, що температура $\epsilon$ інформативним узагальненим діагностичним параметром для визначення технічного стану цифрового РЕО. 
Сучасні Т3 - це складне цифрове PEO 3 різноманітними функціями, великим об'ємом пам'яті та швидкодією. Основою цього обладнання $\epsilon$ BIC, а саме: мікропроцесори та мікроконтролери. Аналіз технології виготовлення таких $\mathrm{BIC}[1,15,16]$ показав, що процес виготовлення включає в себе більше ніж 300 етапів. Основні з яких:

- вирощування кристалу циліндричної форми;

- розрізання кристалу на пластини та полірування;

- створення напівпровідникових структур за допомогою методу фотолітографії шляхом введення донорних ( $n$-типу) чи акцепторних ( $p$ типу) домішок у визначених місцях;

- травлення пластини шляхом занурення розчин сульфату міді для з'єднання логічних елементів, які були створенні метод фотолітографії;

- повторне полірування пластини;

- вибіркове тестування кристалів;

- розрізання протестованої пластини на вироби;

- герметизація та корпусування виробу.

Механічно ВIC - це сукупність підложки (на якій створено електричний i механічний інтерфейс), кристалу та кришки для розподілу тепла, тобто багатошарова конструкція.

Таким чином, вирішення такої задачі технічного діагностування, як локалізація несправності, для ВIC - недоцільно, оскільки, усунути виявлений дефект не представляється можливим, саме тому потрібно вдосконалювати методи, методики та створювати нові підходи у вирішенні інших задач - визначення та прогнозування ТC, що дадуть можливість визначити термін працездатності таких ВIC (даного устаткування), тим самим запобігти негативним наслідкам у випадку раптових відмов.

Аналіз робіт $[1,2]$ в яких досліджено передачу діагностичної ознаки від джерела (напівпровідникового кристалу) на поверхню ізолюючого шару, взаємозв'язок внутрішньої температури 3 теплофізичними параметрами захисного шару та часом розповсюдження тепла, а також роботи [3, 4] в яких розглянуто пристрої реєстрації та методику вимірювання ДП, вказав нові напрямки у вирішенні іншої задачі прогнозування ТС.

Метою статті $\epsilon$ визначення умов застосування методу власного випромінювання (визначення часу реєстрації діагностичного параметру) для складних напівпровідникових ВIC, які містять в собі декілька окремих ФВ 3 відомим місцем розташування на підложці.

\section{Виклад основного матеріалу дослідження}

Особливість застосування методу власного випромінювання для вирішення задач технічної діагностики в даному випадку полягає в тому, що відстань між ФВ та відстань до поверхні ВІС є величинами одного порядку, тому значення ДП можуть бути спотворені внаслідок взаємного впливу ВФ. Відповідь на час реєстрації ДП полягає в аналізі умов розповсюдження тепла у захисному (ізолюючому) шарі напівпровідникової структури, його фізичними властивостями, часом активації ФВ, чутливістю засобу реєстрації [5]. та можливістю екстраполяції отриманих даних.

Метод власного випромінювання пов'язаний 3 реєстрацією параметрів електромагнітного поля в інфрачервоному діапазоні хвиль. Відомо, що параметри цього випромінювання безпосередньо залежать від температури об'єкту контролю [6]. Отже, використання діагностичного параметру вимагає переходу до іншого аналітичного опису напівпровідникових структур, при якому, фізикохімічні процеси в напівпровідниках пов'язуються 3 термодинамічними властивостями кристалічної структури та поверхні, яка герметизує та ізолює кристал від зовнішнього середовища.

Температурне поле, як сукупність значень температури Т всіх точок системи в даний момент часу $\mathrm{t}$, може змінюватися за координатами $\mathrm{x}, \mathrm{y}, \mathrm{z}$ та за часом $\mathrm{t}$ (якщо температурне поле змінюється за часом, воно називається нестаціонарним). У просторі температурне поле може змінюватися по координатам (одній, двом або по всіх трьом). Відповідно до цього, в загальному випадку, маємо тривимірне нестаціонарне температурне поле [7].

Тривимірне нестаціонарне температурне поле 3 урахуванням геометрії BIC та особливостей монтажу може бути зведена до одновимірного наближення, а реєстрація діагностичного параметру здійснюватиметься в напрямку перпендикулярному поверхні BIC [3]. Одновимірна пряма задача нестаціонарної теплопровідності в багатошаровому об'єкті полягає у визначенні температури зовнішньої поверхні в залежності від температури внутрішнього слою (джерела нагріву температури напівпровідникової структури) [7].

Теплофізичні характеристик матеріалів багатошарової конструкції вважаються постійними всередині кожного 3 шарів, а отже, залежать від координати z. Значення теплофізичних характеристик матеріалу шарів об'єкту, що досліджується визначаються наступними параметрами: $\mathrm{T}(\mathrm{z}, \mathrm{t})-$ залежність температури від координати $\mathrm{z}$ i часу $\mathrm{t}$; $\mathrm{c}(\mathrm{z})-$ питома теплоємність, $\rho(z)-$ щільність, $\quad \lambda(z)-$ коефіцієнт теплопровідності.

У відповідності до законів теплопередачі теплова енергія, яка виділяється в напівпровідниковій структурі внаслідок виконання основних функцій або під впливом перевірної тестової послідовності, надалі переноситься назовні, у бік убування температури [2].

Основний закон теплопровідності - закон Фур'є - встановлює кількість тепла q $\left[\mathrm{BT} / \mathrm{m}^{2}\right]$ переданого поверхнею ВIC (кількість тепла, яка переноситься через деяку поверхню $\mathrm{S}$ за одиницю 
часу), де: q - щільність теплового потоку вектор, напрям якого збігається 3 напрямом розповсюдження тепла в даній точці і протилежно спрямований напряму вектора градієнта температури.

Градієнт температури - вектор, спрямований по нормалі до ізотермічної поверхні у бік зростання температури:

$$
\lim _{\Delta \mathrm{n} \rightarrow 0} \frac{\Delta \mathrm{T}}{\Delta \mathrm{n}}=\frac{\mathrm{dT}}{\mathrm{dn}}=\operatorname{gradT} .
$$

Кількість тепла (пропорційна градієнту температури) - межа відношення приросту температури $\Delta \mathrm{T}$ до відстані між ізотермами $\Delta \mathrm{n}$ при прагненні останнього до 0 :

$$
\mathrm{q}=-\lambda \operatorname{gradT}
$$

Коефіцієнт теплопровідності ( $\lambda$ ) характеризує фізичну властивість шару, який вкриває кристал напівпровідника:

$$
\lambda=\left|-\frac{\mathrm{q}}{\operatorname{gradT}}\right|=\frac{\mathrm{Ql}}{\mathrm{St} \Delta \mathrm{T}}=\frac{\mathrm{Pl}}{\mathrm{S} \Delta \mathrm{T}},
$$

де $\mathrm{Q}$ - теплова енергія, яка переноситься [Дж]; $\mathrm{P}=\mathrm{Q} / \mathrm{t}$ - тепловий потік $\left[\mathrm{BT} / \mathrm{M}^{2}\right]$ через поверхню $\mathrm{S} ; \Delta \mathrm{T}$ - зміна температури в тілі на відстані 1[2].

Розв'язання задачі нестаціонарної теплопровідності в багатошаровому об'єкті полягає у визначенні теплофізичних характеристик шарів за заданими часовими залежностями температури біля поверхні BIC i температури самої поверхні:

$$
\mathrm{T}=\frac{\mathrm{U}-\varphi_{30}}{\frac{\mathrm{k}}{\mathrm{q}} \ln \frac{\mathrm{i}(\mathrm{t})}{\mathrm{I}_{0}}-\varepsilon_{3}},
$$

де Т - температура поверхні;

U - напруга, прикладена до переходу;

$\varphi_{30}$ - ширина забороненої зони при нульовій температурі;

k - постійна Больцмана; q - заряд електрона;

$\mathrm{I}_{0}$ - величина струму, який не залежить від температури;

$\mathrm{i}(\mathrm{t})$-значення струму через напівпровідник 3 урахуванням зовнішнього впливу та фізикохімічних процесів, які відбуваються під час експлуатації;

$$
\varepsilon_{3}-\text { температурна чутливість. }
$$

Вираз (1) дозволяє отримати залежність температури кристалу складної напівпровідникової структури від струму через p-n перехід та визначити нагрівання кристала напівпровідника або кількість теплоти, як діагностичний параметр процесів, що відбуваються в напівпровіднику [1].

Для отримання значення температури поверхні BIC в статичному режимі представимо захисний шар ВIC у вигляді пласкої поверхні завтовшки $\mathrm{h}$ площею $\mathrm{S} \quad 3$ матеріалу 3 коефіцієнтом теплопровідності $\lambda$ (рис.1). До внутрішньої стінки пласкої поверхні 3 боку напівпровідникового кристалу поступає рівномірно розподілений за площею тепловий потік Р. Теплопровідністю це тепло передається до протилежної - зовнішньої поверхні, на якій підтримується (присутня) температура $\mathrm{T}_{0}[4]$.

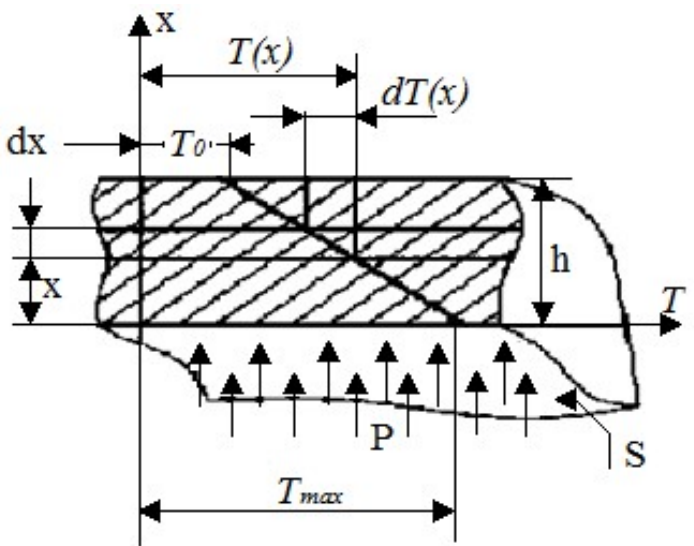

Рис. 1. Розподіл тепла в захисному шарі, який вкриває кристал напівпровідникової структури.

Розподіл температури в пластині представлено у вигляді лінійної функції:

$$
\begin{gathered}
\mathrm{T}(\mathrm{x})=\mathrm{T}_{0}+\frac{\mathrm{Ph}}{\lambda \mathrm{S}}\left(1-\frac{\mathrm{x}}{\mathrm{h}}\right) ; \\
\mathrm{T}_{\max }=\mathrm{T}_{0}+\frac{\mathrm{Ph}}{\lambda \mathrm{S}} .
\end{gathered}
$$

Різниця температур “нагрітої” внутрішньої та “холодної” зовнішньої поверхні $(\mathrm{x}=\mathrm{h})$ становить:

$$
\Delta \mathrm{T}(\mathrm{x})=\mathrm{T}(\mathrm{x})-\mathrm{T}_{0}=\frac{\mathrm{Ph}}{\lambda \mathrm{S}}\left(1-\frac{\mathrm{x}}{\mathrm{h}}\right) .
$$

Потужності $\mathrm{P}$ в ланцюгах постійного струму визначається: $\mathrm{P}=\mathrm{RI}^{2}$. Звідси[4]:

$$
\Delta \mathrm{T}_{\max }=\frac{\mathrm{Ph}}{\lambda \mathrm{S}}=\mathrm{i}(\mathrm{t})^{2} \mathrm{PR}_{\mathrm{r}},
$$

де $\mathrm{R}_{\mathrm{r}}$ - тепловий опір поверхні, яка вкриває кристал напівпровідника та залежить від розмірів $\mathrm{i}$ властивостей матеріалу захисного шару:

$$
\mathrm{R}_{\mathrm{T}}=\frac{\mathrm{h}}{\lambda \mathrm{S}} \text {. }
$$

Модель розподілу температури поверхні ВIC в статичному режимі (сталий режим) є основою для моделі розподілу температури поверхні напівпровідникового ВIC в динамічному режимі.

Розглянемо динаміку нагріву поверхні BIC під впливом вхідного сигналу. У ВІС маси $\mathrm{m}$, який має температуру $\mathrm{T}_{0}$, рівну температурі навколишнього середовища, у момент часу $\mathrm{t}=0$ починає рівномірно за об'ємом виділятися потужність Р. Перепади температури усередині захисного шару кристалу ВIC відсутні. Внаслідок нагріву ВIC віддає енергію в навколишнє середовище через тепловий опір $\mathrm{R}_{\mathrm{r}}$.

$\mathrm{y}$ момент часу $\mathrm{t}$ BIC має температуру $\mathrm{T}$ i за проміжок часу dt змінює іï на dT. Енергія, яка виділяється в кристалі напівпровідника за час dt, дорівнює Pdt i витрачається на нагрів захисного шару на dT i на тепловідвід в навколишнє 
середовище. Енергія, яка піде на нагрів захисного шару - mcdT, а в навколишнє середовище[8]:

$$
\frac{\mathrm{T}-\mathrm{T}_{0}}{\mathrm{R}_{\mathrm{T}}} \mathrm{dt} .
$$

Вираз для визначення температури поверхні в динамічному режимі має вид [8]:

$$
\mathrm{T}=\mathrm{T}_{0}+\mathrm{i}(\mathrm{t})^{2} \mathrm{PR}_{\mathrm{r}}\left(1-\mathrm{e}^{-\frac{\mathrm{t}}{\mathrm{mcR}_{\mathrm{T}}}}\right) .
$$

Час, необхідний для нагріву поверхні ВIC від температури $\mathrm{T}_{1}$ до $\mathrm{T}_{1}$ (рис. 2 ):

$$
\mathrm{t}_{\mathrm{A}}=\mathrm{mcR}_{\mathrm{T}} \ln \frac{\mathrm{T}_{\max }-\mathrm{T}_{1}}{\mathrm{~T}_{\text {max }}-\mathrm{T}_{2}} .
$$

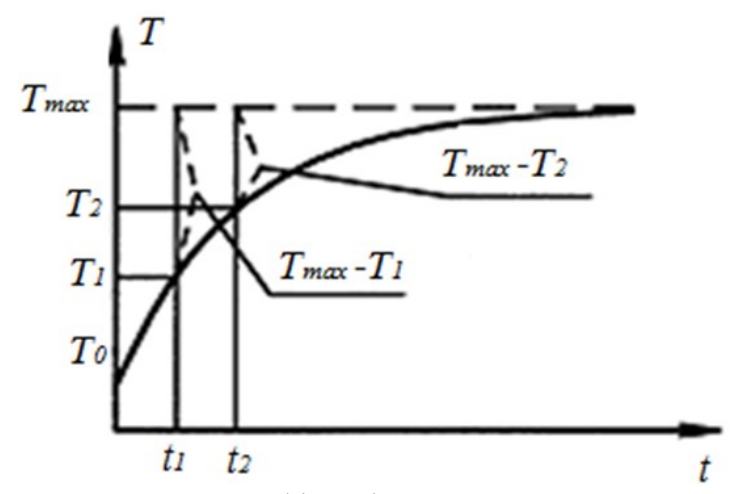

Рис. 2. Графік зміни значення температури поверхні ВІС від часу нагріву.

Зі збільшенням часу нагріву температура поверхні BIC безперервно наближається до $\mathrm{T}_{\max }$, досягаючи цього значення при $\mathrm{t} \rightarrow \infty$.

Таким чином, температура поверхні напівпровідникового приладу (BIC) в динамічному режимі залежить (як i у випадку статичного режиму) від теплофізичних параметрів шару, який вкриває напівпровідниковий кристал і потужності джерела нагріву, а також від часових співвідношень довжини та періоду надходження імпульсів вхідного впливу. В методі власного випромінювання потрібно не лише створити умови активізації ФВ шляхом відповідної побудови перевірних тестів, але i врахувати час, який потрібен для встановлення режиму термодинамічної рівноваги для нього.

В цифровій техніці вхідний вплив являє собою послідовність імпульсів, під дією яких, тепло рівномірно розповсюджується по об'єму ВІС. При детермінованому вхідному впливі нагрів ФВ за час дії імпульсу активації визначається енергією, яка виділяється в імпульсі, i теплофізичними властивостями ізолюючого шару (поверхні ВIC).

Очевидно, що основна вимога до захисного (ізолюючого) шару - забезпечити повну ізоляцію (виключити вплив зовнішнього середовища на напівпровідникову структуру) та забезпечити відвід тепла від кристалу. Для цього використовуються спеціальні матеріали на основі термоактивної, термопластичної полімерної смоли та еластомерних матеріалів, епоксидних чи поліефірних смол. Основні характеристики матеріалів, які використовуються в ізолюючому шарі наведено в таблиці 1 [17].

\begin{tabular}{|c|}
\hline Марка і властивості компаунд \\
\hline $\begin{array}{l}\text { Компаунд К-31 - розора рідина жовтого кольору. При } \\
\text { нагріві компаунда при } 60^{\circ} \mathrm{C} \text { утворюється твердий еластичний } \\
\text { полімер. }\end{array}$ \\
\hline $\begin{array}{l}\text { Компаунд К-168 - епоксидно-діанова смола ЕД-6 } \\
\text { пластифікована поліефіром МГФ-9. В залежності від умов } \\
\text { експлуатації компаунд виготовляють без наповнювачів і } 3 \\
\text { наповнювачами. В якості затверджувача застосовують } \\
\text { гексаметилендіамін, поліетиленполіамін, малеїновий ангідрид, } \\
\text { затверджувач № } 254 \text { та ін. Затвердіння відбувається при } 20^{\circ} \mathrm{C} \text {. } \\
\text { Відрізняється високою механічною міцністю, твердістю, } \\
\text { водостійкістю, стійкістю від грибкової пліснявої. }\end{array}$ \\
\hline $\begin{array}{l}\text { Компаунд Виксинт К-18 }- \text { стійкий до нагрівання } \\
\text { еластичний матеріал. Створений на основі пасти К та } \\
\text { каталізатору №18. При їх змішуванні при температурі } 20^{\circ} \mathrm{C} \\
\text { відбувається вулканізація пасти К, яка переходить в } \\
\text { гумоподібний стан. }\end{array}$ \\
\hline
\end{tabular}

Таблиця 1

Основні властивості та особливості застосування матеріалів ізолюючого шару

В таблиці 2 наведено електричні параметри матеріалів ізолюючого шару [17].

Таблиця 2

Електричні характеристики деяких компаундів

\begin{tabular}{|c|c|c|c|}
\hline Показник & К-31 & К-168 & К-18 \\
\hline $\begin{array}{c}\text { Електрична міцність, МВ/м, } \\
\text { при } 20^{\circ} \mathrm{C}, \text { не менше. }\end{array}$ & 27 & - & 15 \\
\hline $\begin{array}{c}\text { Питомий об'ємний опір, Ом·м, } \\
\text { при } 20^{\circ} \mathrm{C}, \text { не менше. }\end{array}$ & $10^{12}$ & $10^{10}$ & $10^{11}$ \\
\hline $\begin{array}{c}\text { Відносна діелектрична } \\
\text { проникність, при } 20^{\circ} \mathrm{C}, \text { не більше }\end{array}$ & 5 & - & 3 \\
\hline $\begin{array}{c}\text { Тангенм кута діелектричних } \\
\text { втрат при } 20^{\circ} \mathrm{C}, \text { не більше. }\end{array}$ & 0,075 & 0,1 & 0,02 \\
\hline
\end{tabular}

Галузь застосування

Застосовується для заливки різних деталей,

які працюють в інтервалі від $-80^{\circ} \mathrm{C}$ до $+120^{\circ} \mathrm{C}$

Компаунд застосовують для просочення, обтікання, заливки, склейки та герметизації різних деталей та вузлів апаратури для захисту радіоапаратури від впливу вологи та грибкової пліснявої при робочих температурах від $-60^{\circ} \mathrm{C}$ до $+120^{\circ} \mathrm{C}$. По стійкості до нагрівання відноситься до класу Е.

Застосовують для герметизації електро- та радіовиробів, які працюють в інтервалі температур від $-60^{\circ} \mathrm{C}$ до $+250^{\circ} \mathrm{C}$ i в умовах підвищеної вологості.

Епоксидні формувальні компаунди володіють рядом переваг над звичайними термореактивними формувальними компаундами [18]:

- стабільність розмірів затверділого продукту;

- електричні і механічні властивості, які для правильно підібраної композиції зберігаються до $150{ }^{\circ} \mathrm{C}$;

- висока хімостійкість.

Однак, у епоксидних компаундів $є$ і недоліки:

- епоксидні формувальні компаунди дорожчі, ніж звичайні термореактивні компаунди;

- певні труднощі при вийманні виробів 3 
форми;

- для запобігання появі зайвого грата внаслідок текучості компаундів форма повинна бути герметичною.

- оскільки текучість компаундів сильно залежить від температури, то потрібен суворий контроль температури.

Нагрів кристалу не одразу відображується на поверхні ВIC, оскільки діагностичний параметр (температура) формується відповідно способу перенесення теплової енергії. При цьому, довжина активуючого впливу (тесту) визначається не лише технологією виготовлення ВIC, фізичними та електричними властивостями ізолюючого шару, але й геометричними розмірами об'єкту контролю.

Розмір виробу визначається відповідними стандартами. На рис. 3 представлено варіант будови та розміри одного 3 типів корпусів BIC (тип 8, підтип 81) [19].

В таблиці 3 наведено числові значення геометричних розмірів: $n$-загальна кількість можливих позицій; $e$, ном. - крок позиції виводів, які знаходяться в одній площині; z, $\mathrm{z}_{1}-$ звідси корпусу; $\varnothing b$-діаметр виводу на довжині $L ; L-$ довжина виводів; $D$-довжина виробу без врахування виводів; $E$-ширина виробу без врахування виводів; $h$-відстань від установчої площини до верхньої точки виробу (товщина ізолюючого шару) [19].

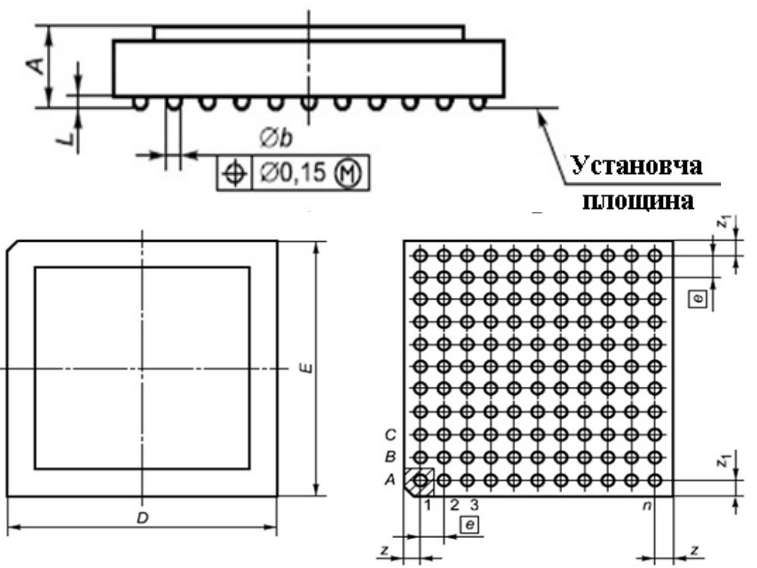

Рис. 3. Корпус ВIC типу 8 , підтипу 81 .

Геометричні розміри корпусів ВIC типу 8 підтипу 81

\begin{tabular}{|c|c|c|c|c|c|c|c|c|c|c|c|c|}
\hline \multirow[b]{2}{*}{$\begin{array}{c}\text { Шифр } \\
\text { типороз } \\
\text {-міру }\end{array}$} & \multirow[b]{2}{*}{$n$} & \multirow[b]{2}{*}{$\begin{array}{c}e, \\
\text { ном }\end{array}$} & \multirow[b]{2}{*}{$\begin{array}{c}\text { z, не } \\
\text { більш } \\
\text { е }\end{array}$} & \multirow{2}{*}{$\begin{array}{c}\mathrm{Z1}, \\
\text { не } \\
\text { більш } \\
\text { е } \\
\end{array}$} & \multirow{2}{*}{$\begin{array}{c}\varnothing b, \\
\text { не } \\
\text { більш } \\
\text { е }\end{array}$} & \multicolumn{2}{|c|}{$L$} & \multicolumn{2}{|c|}{$D$} & \multicolumn{2}{|c|}{$E$} & \multirow[b]{2}{*}{$h$} \\
\hline & & & & & & $\begin{array}{c}\text { не } \\
\text { менше }\end{array}$ & $\begin{array}{c}\text { не } \\
\text { більше }\end{array}$ & $\begin{array}{c}\text { не } \\
\text { менше }\end{array}$ & $\begin{array}{c}\text { не } \\
\text { більше }\end{array}$ & $\begin{array}{c}\text { не } \\
\text { менше }\end{array}$ & $\begin{array}{c}\text { не } \\
\text { більше }\end{array}$ & \\
\hline 8101 & 60 & \multirow{10}{*}{0,80} & 2,2 & 2,40 & \multirow{5}{*}{0,50} & \multirow{10}{*}{0,25} & \multirow{10}{*}{0,35} & 8,70 & 9,30 & 15,70 & 16,30 & \multirow{4}{*}{1,2} \\
\hline 8102 & 64 & & 1,2 & 2,60 & & & & 7,70 & 8,30 & 13,70 & 14,30 & \\
\hline 8103 & 64 & & 1,7 & 0,35 & & & & 8,70 & 9,30 & 11,20 & 11,80 & \\
\hline 8104 & 66 & & 1,2 & 1,60 & & & & 7,70 & 8,30 & 11,70 & 12.30 & \\
\hline 8105 & 80 & & 1,3 & 2,40 & & & & 8,70 & 9,30 & 15,70 & 16,30 & 1.4 \\
\hline 8106 & 90 & & 2.2 & 0,90 & 0,55 & & & 9,70 & 10,30 & & & \multirow{5}{*}{1.2} \\
\hline 8107 & 90 & & 2,7 & 0,90 & \multirow{4}{*}{0,50} & & & 10,70 & 11,30 & 12,70 & 13,30 & \\
\hline 8108 & 144 & & 1,7 & 2,70 & & & & & & 14,70 & 15,30 & \\
\hline 8109 & 195 & & 1,7 & 1,90 & & & & 12,70 & 13.30 & 12,30 & 15,00 & \\
\hline 81010 & 234 & & 1,7 & 0,70 & & & & & & 14,70 & 15,30 & \\
\hline 81014 & 400 & \multirow{2}{*}{1,00} & 1,0 & 1,00 & 0,60 & 0,50 & 0,7 & 20,67 & 21,00 & 20,67 & 21,00 & \multirow{2}{*}{2,9} \\
\hline 81015 & 680 & & 0,5 & 0,50 & 0,70 & 1,50 & 1,7 & 39,80 & 40,30 & 39,80 & 40,30 & \\
\hline 81016 & 256 & 1,27 & 1,4 & 1,40 & 0,60 & 0,65 & 0,90 & 28,71 & 29,29 & 28,71 & 29,29 & 2,8 \\
\hline
\end{tabular}

Час визначення технічного стану $\mathrm{t}_{\mathrm{TC}}$ методом власного випромінювання визначається двома складовими: часом реєстрації діагностичної інформації та часом прийняття рішення (часом обробки інформації). В свою чергу, час прийняття рішення залежить лише від потужності обчислювальних засобів і на сьогодні практично не має технічних обмежень [9]. Таким чином, час визначення технічного стану $\mathrm{t}_{\mathrm{TC}}$ методом власного випромінювання визначається виключно часом реєстрації діагностичної інформації, який залежить від часу прояву діагностичного параметру на поверхні BIC - часу виходу BIC на сталий режим. Тобто, перевірна послідовність подається на обраний об'єкт контролю (ФВ) доти, доки ДП (температура поверхні) не досягне сталого режиму. [8,9].

3 характеристик виробів можливо чітко визначити геометричну прив'язку основних функціональних вузлів (ФВ) сучасного виробу.
Наприклад в процесорі Intel Sandy Bridge налічувалося близько 995 млн. транзисторів (n-p-n

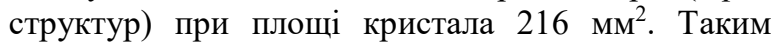
чином розмір сторони виробу становить близько 14 мм. При цьому, до складу даних виробів входить 8 окремих ФВ [10], середня відстань між центрами яких становить близько 2 мм (виходячи 3 площі кристалу та кількості ФВ). При цьому товщина ізолюючого шару, відповідно до табл. №3 знаходиться в межах 1,2-2,9 мм. Звідси маємо висновок - при реєстрації діагностичного параметру (температури) довжину перевірної послідовності необхідно обмежувати оскільки $\mathrm{y}<\mathrm{h}$ (відстань між ФВ менша ніж товщина ізолюючого шару). Отримане при цьому значення ДП $\mathrm{T}_{\mathrm{h}}<\mathrm{T}_{\mathrm{y}}$, що не відповідає температурі в сталому режимі. Реальне значення ДП, яке можливо використовувати при вирішенні задач технічного діагностування буде визначатися шляхом лінійної екстраполяції, або за 
графіком рис.3.

Довжина активуючого впливу $\mathrm{t}_{\mathrm{A}}$ визначається з виразу (2) і має вид:

$$
\mathrm{t}_{\mathrm{A}}=\mathrm{mc} \frac{\mathrm{h}}{\lambda \mathrm{S}} \ln \frac{\mathrm{T}_{\text {max }}-\mathrm{T}_{\mathrm{y}}}{\mathrm{T}_{\text {max }}-\mathrm{T}_{\mathrm{h}}},
$$

де $\mathrm{T}_{\mathrm{y}}-$ температура на відстані між ФВ; $\mathrm{T}_{\mathrm{h}}$ температура поверхні ізолюючого шару.

Дійсне значення ДП буде визначено шляхом лінійної екстраполяції, або за графіком рис. 3. Такий підхід при формуванні активуючого впливу дозволяє знизити взаємний вплив ФВ один на одного та спотворення діагностичної інформації.

\section{Висновки і перспективи подальших досліджень}

В статті визначено умови застосування методу власного випромінювання для складних напівпровідникових структур, які містять в своєму складі декілька окремих функціональних вузлів 3 відомим геометричним місцем розташування на підложці. При вирішенні задач технічного діагностування, застосування необмеженого активуючого тестового впливу може спотворювати значення діагностичного параметра для суміжних функціональних вузлів, оскільки відстань між ними та відстань до поверхні напівпровідникової структури (товщина захисного шару) $є$ величинами одного порядку. Визначення необхідної довжини активуючої тестової послідовності полягає в аналізі умов розповсюдження тепла у захисному шарі напівпровідникової структури, його фізичних властивостях, чутливістю засобу реєстрації та можливістю екстраполяції отриманих результатів.

Напрямом подальших досліджень $є$ отримання екстраполяційних характеристик діагностичного параметру за різною тривалістю активуючої тестової послідовності.

\section{Jimepamypa}

1. Кузавков В.В., Гайдур Г.І., Серих С.О. Аналіз структури напівпровідникових радіоелектронних компонентів для розв'язування задачі нестаціонарної теплопровідності в багатошаровому об'єкті. Журнал ДУТ: Зв'язок. Київ, 2014. №3. С. 44-47. 2. Кузавков В.В., Романенко М.М. Аналіз фізичних можливостей теплового моніторингу як методу оцінки фактичного стану цифрових радіоелектронних об'єктів. Науково-практичний журнал ДНДІ МВС України: Сучасна спеціальна техніка. Київ, 2020. № 2 (61). С. 3446. 3. Романенко М.М. Спосіб реєстрації діагностичної інформації для контролю технічного стану радіоелектронного обладнання. Пріоритетні напрямки розвитку телекомунікачійних систем та мереж спечіального призначення: збірник наукових праць XIII науково-практичної конференції 03.12.2020. Київ: ВITI, 2020. С. 236-237. 4. Кузавков В.В., Романенко М.М. Методика вимірювання діагностичного параметру визначення технічного стану складних напівпровідникових структур. Науково-практичний журнал ДНДІ МВС України: Сучасна спещіальна техніка. Київ, 2021. № 1 (64). С. 54-70. 5. Романенко М.М. Застосування тепловізійних систем для реєстрації діагностичного параметра в методі власного випромінювання. Проблеми інформатизаиії: збірник тез доповідей VIII Міжнародної науковотехнічної конференції 26-27.11.2020. Черкаси - Харків Баку - Бельсько-Бяла. Том 3. Секція 5-7. 2020. С. 107. URL: http://kist.ntu.edu.ua/konferencii/ 26 konf 2020.pdf. 6. Кузавков В.В., Романенко М.М. Аналіз теплових моделей дослідження деградації напівпровідникових структур. Збірник наукових праџь ВITI. №2. Київ, 2020. С. 35-42. 7. Кузавков В.В., Гайдур Г.І., Серих С.О. Діагностична модель $p$ - $n(n-p)$ переходу для методу власного випромінювання. Телекомунікаційні та інформаційні технологіӥ: науковий журнал. Київ: ДУТ, 2015, №1 С.39-43. 8. Кузавков В.В. Забезпечення робочого режиму радіоелектронних компонентів у методі власного випромінювання. Правове, нормативне та метрологічне забезпечення системи захисту інформації в Україні: науково-технічний збірник. Київ: НТУУ “КПІ”, 2015. №1 (29). С. 97-101.
9. Кузавков В.В., Гайдур Г.І. Час локалізації несправного радіоелектронного компоненту методом власного випромінювання. Актуальні проблеми розвитку науки $i$ техніки: збірник тез доповідей I міжнародної науково-технічна конференції. Київ: ДУТ, 2015. С. 101-104. 10. Кузавков В.В., Романенко М.М. Тепловий неруйнівний контроль складних напівпровідникових структур радіоелектронного обладнання. Збірник наукових праць ВITI. Київ, 2019. №2. С. 38-44. 11. Кузавков В.В., Янковський О.Г. Застосування методу власного випромінювання для технічної діагностики радіоелектронних блоків. Збірник наукових пращь ОДАТРЯ. Одеса, 2014. №2 (5). С. 58-62. 12. R. Cochran, A. N. Nowroz and S. Reda. Post-silicon power characterization using thermal infrared emissions. $A C M$ :IEEE International Symposium on Low-Power Electronics and Design (ISLPED). 2010, pp. 331-336. doi: URL: https://scale.engin.brown.edu/pdfs/islped10.pdf.

3. Reda K., Dev and A. Belouchrani. Blind Identification of Thermal Models and Power Sources From Thermal Measurements: IEEE Sensors Journal. vol. 18, no. 2, pp. 680-691. 2018. doi: 10.1109/ JSEN. 2017.2774704. URL: https://ieeexplore.ieee.org/document/8 113493/figures\#figures. 14. Клюев В.В., Вавилов В.П. Неразрушаюший контроль. Тепловой контроль: книга 1. М.: Машиностроение, 2006. Том 5. 688 с. ISBN 5-21703364-9. 15. Чернозубов Ю. С. Как рождаются микросхемы: книга. М.: Просвещение, 1989. 128 с. ISBN 5-09-001314-1. 16. Лебецкий Д. И. Технология производства процессоров. URL: https://rep.bntu.by/bitstream/

handle/data/26857/\%D0\%A1.\%20363-367.pdf? seque nce $=1$. 17. Энциклопедия по машиностроению XXL: фрагменты и выдержки с книги. С. 189-193: URL https://mash-xxl.info/page/ 14709016518720218 105208145222011220142228148241/.18. Технологія виробництва епоксидних смол. Хімія: курсова робота. URL: $\quad \underline{\text { http://4ua.co.ua/chemistry/xa3ad78a5d }}$ 43b89421206d37 0.html. 19. ГОСТ $\quad$ P $54844-2011$ Микросхемы интегральные. Основные размеры URL: https://www.rts-tender.ru/poisk/gost/r-54844-2011. 


\title{
УСЛОВИЯ ПРИМЕНЕНИЯ МЕТОДА СОБСТВЕННОГО ИЗЛУЧЕНИЯ ПРИ РЕШЕНИИ ЗАДАЧ ТЕХНИЧЕСКОЙ ДИАГНОСТИКИ ПОЛУПРОВОДНИКОВЫХ СТРУКТУР
}

\author{
Василий Викторович Кузавков (доктор технических наук, доцент) \\ Мария Михайловна Романенко \\ Юлия Владимировна Болотюк
}

\section{Военный институт телекоммуникаций и информатизации имени Героев Крут, Киев, Украина}

В статье рассмотрены особенности применения метода собственного излучения для сложных полупроводниковых структур (микропрочессоров, микроконтроллеров, программируемых логичных интегральных схем и др.)

Метод собственного излучения связан с регистрацией параметров электромагнитного поля 6 инфракрасном диапазоне волн. Параметры этого излучения напрямую зависят от температуры объекта контроля - температуры полупроводниковой структуры. Использование температуры 6 качестве диагностического параметра требует аналитического описания процессов 6 полупроводниковых структурах, а именно физико-химических процессов, связанных с термодинамическими свойствами кристаллической структуры и изолируемой поверхности кристалла от внешней среды.

С изелью активации функциональных узлов, которые входят в состав больших интегральных схем в предложенном методе используется специильно подготовленная тестовая последовательность. Длина указанной последовательности долюна обеспечить выход температурного прочесса на установившийся режим. Однако, при этом возможно искажение диагностической информации в результате взаимного влияния температуры от соседних функциональных узлов. В работе определено время регистрачии (длину активирующего влияния) диагностического параметра отдельных функииональных узлов. Проанализированы условия распространения тепла в изолирующем слое полупроводниковой структуры, которая включает в себя несколько отдельных функциональных узлов с известным геометрическим местом расположения на подложке.

Исследования направлены на решение задач технического диагностирования, а именно: определение фактического технического состояния ициррового радиоэлектронного оборудования и прогнозирования технического состояния.

Ключевые слова: метод собственного излучения, время регистрация диагностического параметра, радиоэлектронное оборудование, большая интегральная схема.

\section{CONDITIONS OF APPLICATION OF THE METHOD OF OWN RADIATION IN SOLVING TASKS OF TECHNICAL DIAGNOSIS OF SEMICONDUCTOR STRUCTURES}

\author{
Vasyl Kuzavkov (doctor of technical sciences, docent) \\ Mariia Romanenko \\ Julia Bolotyuk
}

\section{Military Institute of Telecommunications and Informatization named after Heroes of Kruty, Kyiv, Ukraine}

The article considers the peculiarities of the application of the method of own radiation for complex semiconductor structures (microprocessors, microcontrollers, programmable-logic integrated circuits, etc.).

The method of own radiation is associated with the registration of the parameters of the electromagnetic field in the infrared wavelength range. The parameters of this radiation directly depend on the temperature of the object of control - the temperature of the semiconductor structure. The use of temperature as a diagnostic parameter requires an analytical description of the processes in semiconductor structures, namely the physical and chemical processes associated with the thermodynamic properties of the crystal structure and the surface that insulates the crystal from the environment.

In order to activate functional units that are part of large integrated circuits, the proposed method uses a specially prepared test sequence. The length of the specified sequence must ensure that the temperature process reaches a steady state. However, in this case, distortion of diagnostic information is possible as a result of the mutual influence of temperature from adjacent functional units. In this work, the registration time (length of the activating influence) of the diagnostic parameter of individual functional units is determined. The conditions of heat propagation in the insulating layer of a semiconductor structure, which includes several separate functional units with a known geometric location on the substrate, are analyzed.

Research is aimed at solving problems of technical diagnostics, namely: determining the actual technical condition of digital electronic equipment and forecasting the technical condition.

Key words: method of own radiation, time of registration of diagnostic parameter, electronic equipment, large integrated circuit. 


\section{References}

1. Kuzavkov V.V., Haidur H.I., Sierykh S.O. Analiz struktury napivprovidnykovykh radioelektronnykh komponentiv dlia rozviazuvannia zadachi nestatsionarnoi teploprovidnosti v bahatosharovomu obiekti. Zhurnal DUT: Zviazok. Kyiv, 2014. №3. P. 44-47. 2. Kuzavkov V.V., Romanenko M.M. Analiz fizychnykh mozhlyvostei teplovoho monitorynhu yak metodu otsinky faktychnoho stanu tsyfrovykh radioelektronnykh obiektiv. Naukovopraktychnyi zhurnal DNDI MVS Ukrainy: Suchasna spetsialna tekhnika. Kyiv, 2020. № 2 (61). P. 34-46. 3.Romanenko M.M. Sposib reiestratsii diahnostychnoi informatsii dlia kontroliu tekhnichnoho stanu radioelektronnoho obladnannia. Priorytetni napriamky rozvytku telekomunikatsiinykh system ta merezh spetsialnoho pryznachennia: zbirnyk naukovykh prats KhIII naukovo-praktychnoi konferentsii 03.12.2020. Kyiv: VITI, 2020. P. 236-237. 4. Kuzavkov V.V., Romanenko M.M. Metodyka vymiriuvannia diahnostychnoho parametru vyznachennia tekhnichnoho stanu skladnykh napivprovidnykovykh struktur. Naukovo-praktychnyi zhurnal DNDI MVS Ukrainy: Suchasna spetsialna tekhnika. Kyiv, 2021. № 1 (64). P. 54-70. 5. Romanenko M.M. Zastosuvannia teploviziinykh system dlia reiestratsii diahnostychnoho parametra $\mathrm{v}$ metodi vlasnoho vyprominiuvannia. Problemy informatyzatsii: zbirnyk tez dopovidei VIII Mizhnarodnoi naukovo-tekhnichnoi konferentsii 26-27.11.2020. Cherkasy - Kharkiv - Baku Belsko-Biala. Tom 3. Sektsiia 5-7. 2020. P. 107. URL: http://kist.ntu.edu.ua/konferencii/ 26_konf_2020.pdf. 6. Kuzavkov V.V., Romanenko M.M. Analiz teplovykh modelei doslidzhennia dehradatsii napivprovidnykovykh struktur. Zbirnyk naukovykh prats VITI. №2. Kyiv, 2020. P. 35-42. 7. Kuzavkov V.V., Haidur H.I., Sierykh S.O. Diahnostychna model r-n (n-r) perekhodu dlia metodu vlasnoho vyprominiuvannia. Telekomunikatsiini ta informatsiini tekhnolohii: naukovyi zhurnal. Kyiv: DUT, 2015, №1 S.39-43. 41-56. 8. Kuzavkov V.V. Zabezpechennia robochoho rezhymu radioelektronnykh komponentiv u metodi vlasnoho vyprominiuvannia. Pravove, normatyvne ta metrolohichne zabezpechennia systemy zakhystu informatsii $\mathrm{v}$ Ukraini: naukovo- tekhnichnyi zbirnyk. Kyiv: NTUU “KPI”, 2015. №1 (29). P. 97-101. 9. Kuzavkov V.V., Haidur H.I. Chas lokalizatsii nespravnoho radioelektronnoho komponentu metodom vlasnoho vyprominiuvannia. Aktualni problemy rozvytku nauky i tekhniky: zbirnyk tez dopovidei I mizhnarodnoi naukovo-tekhnichna konferentsii. Kyiv: DUT, 2015. P. 101104. 10. Kuzavkov V.V., Romanenko M.M. Teplovyi neruinivnyi kontrol skladnykh napivprovidnykovykh struktur radioelektronnoho obladnannia. Zbirnyk naukovykh prats VITI. Kyiv, 2019. №2. P. 38-44. 11. Kuzavkov V.V., Yankovskyi O.H. Zastosuvannia metodu vlasnoho vyprominiuvannia dlia tekhnichnoi diahnostyky radioelektronnykh blokiv. Zbirnyk naukovykh prats ODATRIa. Odesa, 2014. №2 (5). P. 58-62. 12. R. Cochran, A. N. Nowroz and S. Reda. Post-silicon power characterization using thermal infrared emissions. ACM:IEEE International Symposium on Low-Power Electronics and Design (ISLPED). 2010, pp. 331-336. doi: 10.1145/1840845.1840914. URL: https://scale.engin.brown. edu/pdfs/islped10.pdf. 13. Reda K., Dev and A. Belouchrani. Blind Identification of Thermal Models and Power Sources From Thermal Measurements: IEEE Sensors Journal. vol. 18, no. 2, pp. 680-691. 2018. doi: 10.1109/ JSEN.2017.2774704. URL: https://ieeexplore.ieee.org/ document/8113493/figures\#figures. 14. Kliuev V.V., Vavylov V.P. Nerazrushaiushchyi kontrol. Teplovoi kontrol: knyha 1. M.: Mashynostroenye, 2006. Tom 5. 688 p. ISBN 5-217-03364-9. 15. Chernozubov Yu. S. Kak rozhdaiutsia mykroskhemы: knyha. M.: Prosveshchenye, 1989. 128 p. ISBN 5-09-001314-1. 16. Lebetskyi D. Y. Tekhnolohyia proyzvodstva protsessorov. URL: https://rep.bntu.by/bitstream/handle/data/26857/\%D0\%A1. \%20363-367.pdf?seque nce $=1$. 17. Эntsyklopedyia po mashynostroenyiu XXL: frahmentы y vыderzhky s knyhy. S. 189-193: URL: https://mash-xxl.info/page/ 14709016518720218105208145222011220142228148241/.

18. Tekhnolohiia vyrobnytstva epoksydnykh smol. Khimiia: kursova robota. URL: http://4ua.co.ua/chemistry/ xa3ad78a5d3b89421206d37 0.html. 19. HOST R 548442011 Mykroskhemы yntehralnыe. Osnovnые razmerы URL: https://www.rts-tender.ru/poisk/gost/r-54844-2011. 